CESIS Electronic Working Paper Series

Paper No. 296

Learning and Productivity of Swedish Exporting Firms: The importance of Innovation Efforts and the Geography of Innovation

Hans Lööf

Pardis Nabavi

January 2013 


\title{
Learning and Productivity of Swedish Exporting Firms: \\ The importance of Innovation Efforts and the Geography of Innovation
}

\author{
Hans Lööf and Pardis Nabavi \\ Centre of Excellence for Science and Innovation Studies \\ Industrial Economics and Management, Royal Institute of Technology, Stockholm
}

Jan 14, 2013

\begin{abstract}
This paper is concerned with the productivity and growth of Swedish exporting firms. Using data on 9,580 manufacturing firms with 10 or more employees for the period 1997-2008, it estimates a dynamic GMM model that captures both the impact of recurrent knowledge investment through innovation and potential spillovers from the local milieu. The majority of the exporting firms are non-innovative. The data reveal that patent applicants located in knowledge intense milieus account for almost 40 percent of total Swedish exports, but only 2 percent of the firms. From the regressions it is shown that, relative to a firm that does not engage in innovation and has scarce access to external knowledge, the level of productivity is 2-12 percent higher for an innovative firm, depending on how innovation is defined and where the innovator is located. The annual long-run growth rate is $0.2-0.7$ higher for innovative firms. Moreover, the performance gap between innovative and non-innovative exporters increases with accessibility to external knowledge for the former.
\end{abstract}

JEL Classification: C23, F14, L25, O31, R32

Keywords: Productivity, exports, innovation, geographical knowledge spillovers, panel data 


\section{INTRODUCTION}

Recent research has documented and tried to explain substantial performance differences between exporting and non-exporting firms. Firms' learning capacity is central to this literature, but how does firms' learning occur? An extensive literature has investigated the role of international spillovers from foreign markets but provides mixed evidence (Wagner 2007).

The exporting firms' learning might also be associated with their innovation efforts. The theoretical prediction is that the most innovative firms with attractive products and a superior production technology and higher productivity become exporters (Grossman and Helpman 1995). Using micro data, some recent works provide empirical evidence that exports and innovation are interrelated (Cassiman, Golvkoand Martinez-Ros, 2010; Lileeva and Trefler, 2010; Aw et al., 2007; Aw et al, 2011), but the direction of the causality is still an open question.

In addition to customers, competitors, other relations on the export market and internal conditions of the firm related to innovation engagements, the geographical environment is a potentially important complementary source of knowledge. There is a broad consensus in the literature that firms benefit from internal learning, but also that knowledge in an urban region generates spillovers of about the same size as the return from the firms' own investments (Keller, 2010). Feldman (1994) demonstrates the importance of the presence of factors such as specialized business services.

This paper considers the geography of innovation and the role of a particular location for both innovative and non-innovative exporters. We follow the approach in Feldman (1994) and identify 35 different knowledge-intense producer services at the 5-digit level in which the share of employees with a university degree is above 30 percent. These services include ICT, R\&D-engineering, finance, brokerage and recruitment of personnel. For each local economy, our data contains information on the aggregate number and wage sum of these employees, as well as the time distance from each location to all other local economies, enabling us to calculate the accessibility of each firm to specialized business services. 
To capture both internal innovation efforts and external knowledge flows, we use annual information on 9,580 manufacturing Swedish exporters covering a 12-year period, and detailed information about the firms' accessibility to knowledge-intense producer services in 290 municipalities. The panel data is estimated with a dynamic GMM estimator.

To our knowledge, the present study is unique as it is the first country-study ever that, within the same framework: (i) observes the long-run innovation and productivity performance of the exporters in a country, based on annual information of the firms, (ii) includes several alternative innovation proxies, (iii), covers all manufacturing firms with 10 or more employees, and (iv) is able to distribute the firms on detailed geographical levels.

Our data reveals considerable heterogeneity in productivity and growth among the exporting manufacturing firms. Moreover, in contrast to the theoretical predictions by Grossman and Helpman (1995), not only the most innovative firms become exporters. We find that majority of all Swedish manufacturing firms with more than 10 employees can be classified as noninnovative. On average, the non-innovative firms were present on foreign markets for 6-8 years of the 12-year period of our study, compared to 10-11 years for innovative firms. The 132 firms ( 2 percent of the exporters) that are considered persistently innovative based on patent applications, and which are located in milieus with high accessibility to knowledge, account for 38 percent of the total Swedish export value.

The use of various firm-level measures on innovation, together with variation of accessibility to external knowledge observed in our sample, allows us to draw some interesting conclusions on the heterogeneity in performance of exporting firms. First, we find that there is a large number of exporters that are not innovative. Only half of the exporting firms are persistent exporters. Not more than one out of five exporting firms renew their products persistently, and just one out of ten firms is recurrently innovative based on information on patent applications. Second, relative to a firm that does not engage in innovation and has scarce access to external knowledge, the level of productivity is 2-12 percent higher for the innovative firm, depending on the specific location and the specific innovation measure. Third, with the same reference alternative as above, the annual growth rate is about 0.2-0.7 percent higher for innovative firms. Fourth, the performance gap between innovative and noninnovative exporters increases with accessibility to external knowledge for the former category of firms. 
The rest of this paper is organized as follows. Section 2 summarizes the results from previous empirical studies on innovation, productivity and exports, discusses our research objectives and formulate hypotheses. Section 3 presents our methodological approach. Section 4 provides the description of the dataset. The econometric analysis is conducted in Section 5. Section 6 highlights some implications of the results and concludes the paper.

\section{PREVIOUS RESEARCH, MOTIVATION AND HYPOTHESES}

The productivity premium due to self-selection and learning-by-exporting among exporting firms and plants has received substantial attention since the seminal papers by Bernard and Jensen 1995 and 1999. Recently, a growing number of studies have included innovation in the analysis of firm's export performance. Still very few studies include the geography of innovation, comparative measures of innovation, and innovation efforts observed over time. In this section we briefly review the literature on exports, productivity innovation and spatial aspect of innovation before presenting the research framework and objectives.

\subsection{Empirical studies on innovation and exports}

A main research question in the theoretical literature on innovation and exports has been whether innovativeness causes a firm to export, whether the presence on export markets spurs firms' innovation or whether the causality goes in both directions. The early theoretical literature on the relationship between innovation and exporting predicts firms' exporting as a causal effect of their knowledge investments and innovative activities (Vernon 1966; Krugman 1979). In the technology-gap by Hobday (1995), innovation rates are accelerated by foreign consumer demand and, accordingly, a firm's exporting activities. In the endogenous growth model by Grossman and Helpman (1995), trade is recognized as a mechanism to gain access to the knowledge stocks of trading partners, while Aw et al. (2011) suggest a dynamic model with feed-back effects from exports on both innovation and productivity.

Over the last decades, a large number of empirical studies at the micro level have analyzed the importance of firms' innovation engagement as a determinant in the relationship between exports and productivity. One strand of this literature is based on probability estimates. Bleaney and Wakelin (2002), for instance, find that British firms are more likely to export if they are in a sector with a high $R \& D$ intensity ( $\& \& D$ to sales ratio), and Love and Roper (2001) report that British plants with in-house R\&D capability are more likely to export. 
Salomon and Shaver (2005), and Salomon and Jin (2010) present evidence that exporting increases Spanish firms' propensity to innovate, while Cassiman, Golovko and Martinez-Ros (2010) suggests that the causality also goes in the opposite direction; Spanish firms that engage in product innovation significantly have a higher probability of exporting.

Estimating plant-level data from the Taiwanese electronics industry, Aw et al. (2007) find that exporting firms not investing in training (as a proxy for R\&D and innovation) have lower productivity rates than firms investing in training. Complementary results are provided by Criscuolo et al (2005). Analyzing survey data for U.E countries, they document a correlation of innovation, productivity and exports.

Garcia et al. (2012) show that more technology advanced firms benefit more from exporting by increase their productivity compared to less technological firms, which provides some evidence of the role of absorptive capacity in knowledge spillovers. It also supports the idea that firms need comparative technological knowledge and expertise to benefit from external knowledge.

\subsection{Research on innovation and geography}

Thanks to the increasing availability of micro data, research on the link between innovation, productivity and exports has increasingly shifted from aggregate to disaggregate levels. This has contributed to a deeper understanding of the complex process. However, while there are obvious advantages of observing data samples of individually unique production units, this type of research typically also suffer from some problems. One is that resources required to produce innovation are typically not confined to the boundaries of a single firm or plant. Urban economists have convincingly shown that the geography also matters.

Although the trade is considered as a main mechanism to gain access to the "global stock of knowledge", even the largest multinationals are embedded in ecosystems that support and sustain their activity (Gassler and Nones, 2008). Indeed, these systems are globally connected, but their innovation processes are still carried out predominantly in a few key regions (Rugman, 2000).

Recent research in the geography of innovation has established several stylized and commonly accepted facts including: (i) innovation is spatially concentrated, and (ii) 
knowledge spillovers are geographically localized (Feldman and Kogler 2010; or Johansson et al. 2012). Bettencourt et al. (2007) report that large metropolitan areas have disproportionately more patents than smaller areas, implying that increasing returns to innovation exist as a function of city size. Regarding the importance of spillovers, research in this field has produced a large variation in the results, but the majority of studies are centered around the conclusion that a doubling of the city density creates a productivity increase of 3-8 percent (Sveikauskas 1975; Tabuchi 1986; Lööf and Nabavi 2013).

Why is geographical proximity influencing firms' innovation and productivity? A dense nearby environment with a wide spectrum of knowledge resources, and qualifications and competence profiles of the labour supply provides rich opportunities for knowledge exchange and creative interaction between firms and individuals in the region. Transport costs, the rate of return on human capital and innovation will benefit from the increased proximity (Glaeser and Ponzetto, 2010). In addition to reduced transportation and communication costs, theories of agglomeration economies include accumulated knowledge, Marshallian (specialization) or Jacob (variation) externalities, and the thickness of the labour market. Firms and industries benefit in a pronounced way from each other's knowledge and innovation activities (Fujita and Thisse, 2002).

\subsection{Motivation and objectives}

The main motivation for this study is that the existing literature on the learning of exporting firms, the relationship between innovation, productivity and exports, has largely overlooked the geography of innovation. We argue that the local knowledge resources required to generate economically valuable production are typically not restricted to a single firm or a single plant. By including the location of the firms, the study aims to better understand the heterogeneity of the performance of exporting firms, and whether the particular location of a firm can compensate for the lack of internal innovation activities, or augment the effect of innovation efforts.

A second motivation is that many existing studies suffer from poor measurement of firms' innovation activities. Aw et al. (2007), for instance, use investment in training as a proxy for R\&D. Other studies (e.g. Castellini and Zanfei 2007; Harris and Li, 2011) apply crosssectional data from community innovation surveys. However, more recent research has emphasized the importance of sustained recurrence of the innovation-engagement. Such 
differences in a firm's internal accumulation of knowledge remain persistent over time (Klette and Kortum 2004).

Many existing studies observe innovation by means of R\&D-expenditures. However, innovations can be made without formal $\mathrm{R} \& \mathrm{D}$, and a not negligible share of small and middle sized firms conduct research and development but do not report it. Moreover, it is often desirable to use a more direct measure of innovation than the input variable R\&D. Still, focusing on innovation instead of R\&D is also problematic.

A main issue is that there exists no widely accepted definition of innovation. Indeed, thanks to work by the OECD and others, there is a definition of innovation by firms that is fairly standard across countries: "An innovation is the implementation of a new or significantly improved product (good or service), or process, a new marketing method, or a new organisational method in business practices, workplace organisation or external relations" (from OECD's so-called Oslo Manual, 2005). Nonetheless, what is "new" or "significantly improved", or the difference between a radical innovation and an incremental innovation, or the difference between an innovation and an imitation, is less clear.

In this study, we choose to observe the innovative by using three different proxies, each of which contains its own flaws. But our a priori assumption is that all three should give similar, or at least non-conflicting, evidence. The indicators are (i) persistent presence in the export market, (ii) regular renewal of export products, and (iii) regular patent applications. We consider the first indicator as the weakest of the three, since we only assume, without observing it, that a sustained presence on foreign markets requires continuous renewal. The two other measures are both observed in our data, and we consider patent application as the most significant indicator of the firms' innovation activities.

\subsection{Hypotheses}

The discussion of the theoretical and recent empirical literature above leads to the following hypotheses:

Hypothesis 1: Exporters are distinguished by their ability to absorb and assimilate external knowledge. Through learning from spillovers and external knowledge, a non-innovative exporter can compensate for lack of internal learning from innovation activities. This is 
reflected in a positive correlation between accessibility to external knowledge and productivity for non-innovative firms.

Hypothesis 2: Only innovative exporters have a distinct learning capacity. External knowledge gets useful first when it is combined with internal knowledge and capabilities inside the firm. This will result in a systematic difference between innovative and noninnovative regarding exploitation of external knowledge.

Hypothesis 3: Instead of converging, the already divergent level of productivity between innovative and non-innovative exporters becomes more divergent over time due to a systematic difference in the growth rate.

Hypothesis 4: Variations in the local knowledge spillovers influence the growth rate and increase the existing productivity gap between innovative exporters. Innovative exporters in milieus with high accessibility to external knowledge grow faster than other innovative firms.

\section{MODEL AND ESTIMATION FRAMEWORK}

The analysis relies on two measures of firm productivity. The first is value added and the second is total factor productivity, TFP. For the latter, we use the Levinsohn and Petrin ${ }^{1}$ (2003) approach, which is a slightly simplified version of Olley and Pakes (1996) and in line with several other authors (e.g. Silvia et al. 2012). The main difference between these two approaches is that Levinsohn and Petrin (2003) suggest the use of intermediate inputs as a proxy rather than investment which is used in Olley and Pakes (1996). TFP is computed as the residual of the Cobb-Douglas production function where value added of the firm is the dependent variable and labour inputs (divided into highly educated and ordinary labour), material and physical capital are used as determinates. This method is assumed to take care of simultaneity and selection bias in the estimation of production function at plant level.

\footnotetext{
${ }^{1}$ Levinsohn and Petrin (2003) propose using a commonly observable variable (intermediate input) to control for unobserved productivity. Their methodology is based on the following key result: under the assumption of perfect competition, the intermediate input's demand function is a monotonic function of productivity. However, firms in most industries enjoy some degree of market power such that perfect competition may not be a desirable assumption for most empirical studies. This paper contributes to the literature by showing the monotonicity condition holds under monopolistic competition.
} 
Our empirical model is a Cobb-Douglas function. The variables we would like to explain are productivity and productivity growth. The key interest is to determine the elasticity of productivity and growth with respect to a composite variable consisting of different alternatives for innovation combined with different accessibility to external knowledge. The equations used in this paper are:

(1) $y_{i t}=\alpha_{i}+\alpha_{j}+\alpha_{t}+\gamma_{1} y_{i, t-n}+\beta_{1} I S_{i t}+\beta_{2} E M P_{i, t-n}+\beta_{3} P C_{i, t-n}+\beta_{4} H C_{i, t-n}+\beta_{5} E P_{i t}+\beta_{6} O W_{i t}+\varepsilon_{i t}$

(2) $\Delta y_{i t}=\alpha_{i}+\alpha_{j}+\alpha_{t}+\gamma_{1} \Delta y_{i, t-n}+\beta_{1} I S_{i t}+\beta_{2} \Delta E M P_{i, t-n}+\beta_{3} \Delta P C_{i, t-n}+\beta_{4} H C_{i, t-n}+\beta_{5} E P_{i t}+\beta_{6} O W_{i t}+\varepsilon_{i t}$

where we estimate log productivity $\left(y_{i t}\right)$ in equation (1) and growth of log productivity $\left(\Delta y_{i t}\right)$ in equation (2). IS is the interaction variable between innovation and geographically related knowledge spillovers. There is a substantial degree of heterogeneity across firms in our sample. The levels of productivity and productivity growth in some industries are higher than in others due to factors unrelated to innovation and location. We therefore allow for exogenous differences in productivity and growth across industries by including industry effect $\left(\alpha_{j}\right)$. We also include time fixed effects $\left(\alpha_{t}\right)$, because our sample period covers fluctuations over the business cycle and particularly the ICT debacle 2000-2002. The third category of heterogeneity that we allow for is fixed effects for individual firms $\left(\alpha_{i}\right)$. EMP is $\log$ employment, PC is log physical capital, HC is human capital, EP is export participation years, OW is corporate ownership and $\varepsilon$ is the idiosyncratic error term. Since several papers have shown a persistent difference in productivity levels across firms (Syverson 2011; Dosi 2007), we also include lagged labour productivity and lagged growth, respectively among the controls.

The empirical model that we apply is a dynamic one-step system GMM estimator (Arellano and Bover 1995; Blundell and Bond 1998). In order to apply equations (1) and (2) in the GMM framework, we need to classify the variables as endogenous, predetermined, and weakly exogenous and strictly exogenous. Based on the literature, we treat the determinants of productivity, human capital, physical capital and firm size (employment) as endogenous regressors. The endogeneity concern is a possible correlation between these variables and unobserved productivity shocks. 
Our key indicator variable IS and the other dummy variables are all treated as exogenous in the model. It should be noted that the variation over time in IS is almost zero, since the innovation strategy is constant and most firms do not change location during the 12-year observation period. Finding a plausible instrument for this almost constant variable is not possible in the present application (for a similar case, see Lychagin, 2010).

\section{DATA}

\subsection{Key variables}

This study is based on register data on exporting manufacturing firms in Sweden from Statistics Sweden, and EPO's database PATSTAT. Both databases contain annual firm observations over the period 1997-2008. The register data covers 100\% of Swedish manufacturing export from firms with 10 or more employees, and provides information on the firms' value added, exports, employment, human capital (university educated employees), physical capital, ownership, geographical location and industry classification. By merging PATSTAT with the register data we receive information on all firms in Sweden that have applied for a patent nationally or internationally during the period we study.

Our primary interest is whether productivity (value added and total factor productivity) for exporting firms is related to innovation (internally generated knowledge probably linked to foreign customers) and location (externally generated knowledge) or both. We use three different proxies for capturing firm innovation. The first is persistent presence on the export market, which means a persistent exporter exports all the years when the firm is active in foreign markets. The second is the frequency of renewal of their export products. Firms which have created at least 4 new products during the 12-year period are considered to be innovative. Our third innovation measure is patent application. The criterion to be considered innovative here is that the firm has applied for a patent in at least 2 of the 12 years of the period.

In order to capture the impact of location we use knowledge-intensive producer services as a proxy for the mass or amount of influential external knowledge. The approach is the following: First we observe all the exporting and non-exporting, manufacturing and service firms in Sweden, in 290 municipalities. For each of these 290 places we have a specific 
measure showing firm's accessibility to service producers inside and outside the own municipality. Next, the approximately 400,000 existing firms are separated into three evenly distributed groups of municipalities with low, medium and high accessibility. Finally, we observe number of exporting firms in the groups. Thus, our data set allows us to separate the influence of knowledge spillover related to specialized business services from the importance of the density of firms, since the latter is of the same order in all the three groups. Table 3 reports that about 50 percent of the exporters are located in areas with low accessibility to external knowledge, while 36 percent have medium accessibility, and the remaining 14 percent are in local milieus with high accessibility to knowledge.

Combining observations on two different state of innovation activity, and three different types of firm location, we create the interaction variable IS (Innovation and spillover from the surrounding geography) that have 6 different categories: IS1, non-innovative, low accessibility; IS2, non-innovative, medium accessibility; IS3, non-innovative, high accessibility; IS4, innovative, low accessibility; IS5, innovative, medium accessibility; IS6, innovative, high accessibility.

\subsection{Control variables}

There is a broad consensus in the literature that firm size is positively related to productivity due to larger markets, economies of scale and scope and similar factors. Tables 1 and 2 also show that persistent innovators are substantially larger than other firms. In order to isolate the influence of size on productivity, we include the current and lagged number of employees in both equations. Since this variable is considered as potential endogenous, appropriate instruments are included in the model.

An extensive empirical literature has confirmed a significant positive relationship between physical investments and productivity (For early studies, see Cohen and Klepper 1996; Griliches, 1998; Sutton, 1998). Several kinds of relationships are possible: (i) investment in physical capital influences subsequent firm productivity, (ii) firm productivity influences subsequent investment, and (iii) investment and productivity are influenced simultaneously by a third factor or by interdependent dynamics of mutual causation. In this analysis we account for the causality issue with different lag structures of both physical investments and productivity, and include instruments. 
The core of modern growth literature is the idea that human capital and skilled labor enhance productivity. Another central message from a wide range of regional and urban studies suggests that local economies adhering to large urban agglomerations are more innovative and productive than other places. At the same time large urban regions have higher wages and attract highly educated, skilled and creative labour. Hence, it becomes problematic to determine the extent to which higher productivity is caused by a region's productive milieu, and the extent to which it is the consequence of a selective in-migration of skilled persons. In this paper, we follow the literature and try to mitigate the problem of a skewed distribution of talented workers by controlling for the current and lagged share of people with 3 years of university education in each individual company. The variable is treated as endogenous in the models and therefore instrumented.

Firms that belong to a multinational group (MNE firms) stand out as different from others in terms of their propensity to conduct innovation projects and ability to get positive results from their efforts. This phenomenon is often attributed to the diffusion of knowledge that takes place in a multinational group with widely spread intra-group networks. Moreover, the global location of subsidiaries makes it possible for local firms in a group to tap knowledge from different knowledge centers around the world. We account for the relation between ownership and productivity by four different dummy variables represent independent domestic firm, domestic firms that are part of a domestic group, domestically owned multinationals and foreign multinationals.

In the twelve different regressions (3 different innovation measures and 2 different productivity measures for equation 1 , and equation 2 , respectively), we also control for number of years the firm is present on the export market, industry classification at the 2-digit level and 12 year dummies.

\subsection{Summary statistics}

Table 1 reports the descriptive statistics for the three data panels applied in the empirical analysis for the period 1997-2008. In the first category, we define innovation by persistency on the export markets. The upper part of the table shows that nearly half the exporters are present on the export market in all years for which we observe them $(48,7 \%)$. On average, they are present on the export market for 10 years. The second half of the exporters, which we define as non-innovative, export for 6 of the 12-year period. 
The middle section of Table I reveals the summary statistics for the panel when the innovation criterion is renewal of the product. Only one exporting firm out of five introduces new products recurrently. The last section shows that not more than 9 percent of the firms fulfill the requirement of applying for a new patent more than once (one year) during the 12-year period.

For each classification of the firms into non-innovative and innovative exporters, we distribute the firms across places with low, medium and high accessibility to external knowledge.

Irrespectively of how we define an innovative firm, the three data panels show a systematic regularity: Innovative exporters are larger, more human capital intense, more productive, and have higher exports per employee in each location than non-innovative exporters. The innovative exporters are typically owned by a multinational company, while other exporters are independent firms, or belong to a group with only domestic affiliates.

\section{RESULTS}

\subsection{Level of productivity}

Table 2 shows the results for the dynamic GMM regression estimations of equations (1). Coefficient estimates are presented for all three innovation indicators, and two different productivity measures. Panel I reports the results for export persistency, Panel II for new products and Panel III for innovation measured by patent applications. The left column in each panel displays the results when the dependent variable is log value added (VA), and the dependent variable in the right column is log total factor productivity (TFP).

The six key variables (IS1-IS6), reported in the upper part of the table, describe the influence of innovation and location on the productivity of exporting manufacturing firms. Results for the covariates are given in the middle section of the table, and the test statistics for presence of autocorrelation in the error term and endogeneity in the model are shown in the bottom part of the table. 
The first hypothesis test the assumption that exporters are distinguished by having capacity to learn from external sources. The physical location to a knowledge dense area means that a non-innovative company can compensate for the lack of own investments in innovative activities. This is reflected in a positive correlation between accessibility to external knowledge and productivity.

The coefficient estimates for non-innovative shows the following: Relative to the average firm that does not engage in innovation at all, and which is located in a municipality with low access to external knowledge (IS1), no or only weak learning-effect from spillovers can be found in the level of productivity for non-innovators located in areas with medium (IS2) or high accessibility (IS3) to external knowledge. Thus, we reject the hypothesis that noninnovative exporters can have absorptive capacity to internalize external knowledge by assimilating intended and unintended spillovers.

The second hypothesis claims that only innovative exporters have a distinct learning capacity. External knowledge gets useful first when it is combined with internal knowledge and capabilities inside the firm. The composite variable measuring both internal and external knowledge is an increasing function of the spillovers intensity only for innovative firms.

The coefficient estimates for the variables IS5 and IS6 provide support for the hypothesis. The elasticity of productivity with respect to external knowledge is systematically stronger for innovators with medium or high access to specialized business services and other factors associated with knowledge proximity (a thick labour market, related variety to firm that have low cognitive distance in terms of their input combination, Jacobs-type externalities between complementary firms etc.)

The estimates for the IS5-variable (innovative firms in locations with medium access to external knowledge) are within the range 0.03-0.07. Only the TFP-estimate for persistent exporters is outside this range and the coefficient is non-significant. The final key-variable is IS6, and the estimates are within the range 0.05-0.12. The highest estimate is reported for persistent patent applicants in high accessibility areas, and the lowest for persistent exporters in knowledge intense milieus. 
The estimated effect for the covariates shows positive and significant effects for firm size and number of years on the export markets. The coefficients for human capital are sizeable but not significant. No systematic pattern is found for physical capital cross the regressions. Controlling for innovation, location, size, human capital, physical capital and presence on the export market, the results show that multinational ownership has no additional explanatory power.

The statistics reveals that we use between 99 and 211 instruments for the equation including 12 year dummy variables and 13 industry variables (technically they are also instrumented in regression). The Arellano-Bond (AR) tests for zero autocorrelation in the first-differenced error are satisfactory, and the Hansen tests show that the overidentifying restrictions are valid.

\subsection{Productivity growth}

The results for the growth model (equation 2) are presented in Table 3, which follows the same structure as Table 2. The hypotheses to test here is linked to Krugman (1991) who in contrast to the predictions of neoclassical growth theorist, suggests that rather than converging, national economies will become more divergent over time. In the present study, Table 1 shows that innovative firms are more productive than other exporters. Hypothesis 3 , states that these firms also will grow faster than non-innovative firms and increase the productivity gap over time.

The regression results in Table 3 show a distinct and clear pattern: No differences in productivity growth can be found between non-innovators in areas with poor knowledge accessibility. But irrespectively of productivity measure and geographical location, innovative exporters always have higher growth rate than other exporters. Thus, hypothesis 3 cannot be rejected.

The final hypothesis states that variations in the local knowledge spillovers influence the growth rate and increase the existing productivity gap between innovative exporters. The regression results presented show that growth rate among innovators is systematically larger when the output measure is TFP. Moreover, the estimates for growth rates are largest when innovation is observed by patent application, and lowest using persistent presence on the export market as a proxy for innovation. 
The main conclusions regarding hypothesis 4 can be drawn from the dynamic GMM estimates is that innovative exporters in milieus with high accessibility to external knowledge grow faster than other non-innovative firms. Five out of the six regression results for IS4-IS6 in Table 3, show that the growth rate for innovative exporters is positively associated with the accessibility to external knowledge. Only the IS6-estimate for new products deviates from the uniform pattern. The size of the IS6 estimate is lower than the IS5 estimate $(0.063$ versus 0.072). However, the overall conclusion is that Hypothesis 4 cannot be rejected.

Recalculating the coefficient estimates to growth figures, using the average nominal growth rates for IS1 (4 percent) as reference, the point estimates presented for the IS4-variable suggest that the long-run growth rate for IS4 is 0.1-0.3 percent higher. The corresponding growth gap is 0.1-0.5 percent for innovators located in places with medium access to knowledge externalities and 0.2-0.7 for persistent innovative exporters in the most knowledge intense areas.

The results for the control variables reveal that TFP-growth is neutral with respect to employment growth. By construction of the model, the estimate of employment growth in the VA-model is positive. Also due to model specifications, the VA and TFP -results diverge for growth of physical capital. The human capital variables are sizeable, but not significant. In all six regressions, productivity growth is positively linked to the yearly present on the export market, indicating learning-of-exporting. The ownership variables suggest that foreign multinationals have higher growth than domestic firms, ceteris paribus. The bottom part of table 3 , reports that the test statistics is satisfactory.

The summarizing finding concerning the estimates from regressing equation (2) is that the already superior exporters will increase their performance gap to other exporting firms in Sweden. The reason is more efficient internal learning through recurrent annual innovation efforts, higher absorptive capacity and a knowledge intense local environment.

In order to check the robustness of the results we have relaxed the requirement for being classified as innovative, and we have also estimated regressions (1) and (2) with the pooled OLS model and the random fixed model. These checks show that the overall finding presented above is consistent across definitions and models. 


\section{CONCLUSION}

Firms' learning capacity is central to the literature on exports and productivity. But how does learning occur? Theoretical predictions on learning-by-exporting has mainly not been confirming by empirical evidence, while there are strong evidence in favour of self-selection of more productive firms into exporting. Innovation has been suggested as selection mechanism. Ex ante productivity premium of innovators compared to non-innovators influences the decision to start exporting. Recent studies have also confirmed interrelation between innovation and exports, although the causality is still an open question. Thus, exporting firms' learning might be closely linked to their innovation efforts.

However, many importers are not innovative. Our data, consisting of all 9,580 Swedish manufacturing with 10 employees or more that were present on the export markets during a 12 year period, shows that a majority of these firms cannot be classified as innovators. Not more than 1 out 10 firms applied for a patent during more than one year. Only 20 percent are recurrently renewing their products and 50 percent of the exporters are not persistently present on foreign markets.

There is a broad consensus in the literature that firms are learning not only from their own innovation activities, but also from other innovative firms, specialized business services and other kinds of external knowledge. Such spillovers have been found to be spatially concentrated and rapidly diminishing with distance.

By including the location of the exporting firms in the analysis, this study provides evidence whether a particular location of a firm can compensate for the lack of internal innovation activities, or augment the effect of innovation efforts. A main conclusion is that the ability to absorb and assimilate external knowledge differs substantially between innovative and noninnovative exporters.

Using a dynamic GMM-model, our regression results shows that an innovative exporter can increase productivity by up to about 10 percent due to spillovers from the surrounding environment. We find no or only very weak spillover effects for the non-innovative exporters. The external knowledge has a positive and significant impact also on the long-term growth 
rate for innovative firms. No corresponding growth effect is shown for non-innovative exporters.

The results of our study include issues that are potential areas for future research. One such issue concerns persistent innovation engagement. If persistent innovation is good for exporting firms, why aren't all exporters innovative? To become an exporter, a firm must have reached some critical threshold, showing characteristics of self-selection. But for various reasons, a large fraction of the exporters chooses strategy with no, or only temporary renewal of their products and processes. What is the role of financing for this decision? How restrictive is the lack of internal knowledge and expertise in the organization and management for decisions but not explicitly applied on the learning and productivity of exporting firms. 


\section{REFERENCES}

Armando Silva , Oscar Afonso \& Ana Paula Africano (2012), Which manufacturing firms learn by exporting?, The Journal of International Trade \& Economic Development: An International and Comparative Review, 21:6, 773-805

Arellano, M., and Bover, O., (1995). "Another Look at the Instrumental Variable Estimation of Error Component Models." Journal of Econometrics, 68: 29-51.

Aw, B. Y, Roberts, M. J., and Winston, T., (2007). "Export Market Participation, Investments in R\&D and Worker Training, and the Evolution of Firm Productivity", The World Economy, 30, 83-104.

Aw, B. Y, Roberts, M. J., and D. Y. Xu (2011), 'R\&D investment, exporting, and Productivity Dynamics', American Economic Review. American Economic Association, 101:4, 1312-44.

Bernard, A.B., Jensen, J.B., (1995). Exporters, jobs, and wages in U.S. Manufacturing, 19761987. Bookings Papers on Economic Activity, Microeconomics. 67-119

Bernard, A. B. and B. Jensen (1999), Exceptional exporter performance: cause, effect or both?', Journal of International Economics, 4, 1-25

Bettencourt, L.M.A., Lobo, J., Strumsky, D. (2007). "Invention in the city: increasing returns to patenting as a scaling function of metropolitan size". Research Policy 36, 107-120.

Bleaney, M., Wakelin, K., 2002. Efficiency, Innovation and Exports, Oxford Bulletin of Economics and Statistics, v64, 3-15.

Blundell, R., and Bond, S., (1998). "Initial Conditions and Moment Restrictions in Dynamic Panel Data Models.” Journal of Econometrics, 87: 115-143.

Castellini, D. and A. Zanfei (2007), 'Internationalisation, Innovation and Productivity: How DOFirms Differ in Italy?', The World Economy, 30, 1: 156-176.

Cassiman, B., \& Golovko, E., \& Martínez-Ros, E., (2010). "Innovation, exports and productivity," International Journal of Industrial Organization, Elsevier, 28:4, 372376.

Cohen, W., M. \& Klepper, S., (1996). "Firm Size and the Nature of Innovation within Industries: The Case of Process and Product R\&D," The Review of Economics and Statistics, MIT Press, 78:2, 232-43.

Cohen, W., Levinthal, D. (1990). Absorptive capacity: A new perspective on learning and innovation. Administrative Science Quarterly 35(1), 128-158. 
Criscuolo, C., F. Sacca, G. De Michele, P. Mancini, O. Combarros, J. Infante, A. Garcia, S. Banfi, A. Filla, and J. Berciano. (2005). "Novel mutation of SACS gene in a Spanish family with autosomal recessive spastic ataxia”, Mov Disord, 20:10, 1358-1361.

Damijan, J. P. and C. Kostevec and S. Polanec (2010), 'From Innovation to Exporting or Vice Versa?', The World Economy, 30, 1, 374-398

Dosi, G. (2007). Statistical regularities in the evolution of industries. a guide through some evidence and challenges for the theory. In F. Malerba and S. Brusoni (Eds.), Perspectives on Innovation. Cambridge University Press.

Feldman, M. and D. F. Koegler (2010), 'Stylized facts in the geography of innovation', in B. Hall and N. Rosenberg (eds.) The Economics of Innovation, Elsevier

Feldman, M. (1994), “Knowledge complementarity and innovation”, Small Business Economics 6(3): 363-372.

Fujita, M., Thisse, J.F, (2002). Economics of agglomeration: Cities, industrial location and regional growth. Cambridge: Cambridge University Press

García,F., Avella, L., and Fernández, E., (2012) Learning from exporting: The moderating effect of technological capabilities, International Business Review, 21: 6, 1099-1111.

Girma, S., H. Görg and A. Hanley (2008), 'R\&D and Exporting: A Comparison of British and Irish Firms', Review of World Economics , 144, 4: 750-773.

Gassler, H. and B. Nones (2008). 'Internationalisation of R\&D and embeddedness: the case of Austria.' Journal of Technology Transfer, 33: 407-421.

Glaeser E. L., \& Ponzetto G. A. M., (2010). "Did the Death of Distance Hurt Detroit and Help New York?," NBER Chapters, in: Agglomeration Economics, pages 303-337 National Bureau of Economic Research, Inc.

Griliches, Z. (1998), "R\&D and Productivity: The Econometric Evidence," NBER Books, National Bureau of Economic Research, Inc.

Grossman, G. M., \& Helpman, E., (1995). "Trade Wars and Trade Talks," Journal of Political Economy, 103:4, 675-708.

Grossman, G., M. \& Helpman, E., 1991. "Trade, knowledge spillovers, and growth," European Economic Review, Elsevier, 35(2-3), . 517-526.

Harris, R. and J. Moffat (2011), 'R\&D, Innovation and Exporting', SERC Discussion Paper 73.

Harris, R. and Li, Q., C., (2011), 'Participation in export markets and the role of R\&D: establishment level evidence from the UK Community Innovation Survey 2005', Applied Economics, 43:23, 3007-3020. 
Hobday, M. (1995). Innovation in East Asia: The Challenge to Japan. Aldershot, UK: Edward Elgar.

Johansson , B., \& Lööf , H., \& Nabavi, P., (2012), "How can firm benefit from access to knowledge-intensive producer services?", CESIS working paper series 283.

Keller, W. (2010), 'International Trade, Foreign Direct Investment, and Technology Spillover', in B. Hall and N. Rosenberg (eds.) The Economics of Innovation, Elsevier.

Klette, T.J., Kortum, S., (2004). Innovating Firms and Aggregate Innovation, Journal of Political Economy 112, 986-1018.

Krugman, P., (1979), “A Model of Innovation, Technology Transfer, and the World Distribution of Income”, Journal of Political Economy , 87: 2, 253-266

Levinsohn, J. and Petrin, A., (2003), Estimating Production Functions Using Inputs to Control for Unobservables, The Review of Economic Studies , 70: 2 , 317-341

Lileeva, A., \& Trefler, D., (2010). "Improved Access to Foreign Markets Raises Plant-Level Productivity... for Some Plants," The Quarterly Journal of Economics, MIT Press, 125:3, 1051-1099.

Love, J. H and P. Ganotakis (2013), 'Learning bu exporting: lessons from high-technology SMEs' International Business Review, 22: 1-17

Lychagin, S. \& Pinkse, J. \& E. Slade M., E.\& John Van Reenen,J., V., (2010). "Spillovers in Space: Does Geography Matter?", NBER Working Papers 16188, National Bureau of Economic Research, Inc.

Lööf , H., \& Nabavi, P., (2013), ’Increasing return to smart cities”, Regional Science Policy and Practice, forthcoming.

OECD (2005), Oslo Manual: Guidelines for collecting and interpreting innovation data, third edition, Paris: OECD.

Olley, S. and Pakes, A. (1996), "The Dynamics of Productivity in the Telecommunications Equipment Industry", Econometrica, 64 :6, 1263-1298.

Rugman, A, M. (2000). The end of Globalization, Random House: London/Amacon-McgrawHill: New York

Salomon, R. \& B. Jin. (2010). “Do Leading or Lagging Firms Learn More from Exporting?”, $31: 10,1088-1113$.

Salomon, R, \& Shaver, J., (2005), 'Learning by Exporting: New Insights from Examining Firm Innovation', Journal of Economics \& Management Strategy, 14: 2, 431-460

Sutton, J. (1998), Market Structure and Technology. Cambridge, Mass. MIT Press. 
Sveikauskas, L.A., (1975). The productivity of cities. Quarterly Journal of Economics, 89, 392-413.

Syverson, C., (2011) "What Determines Productivity?," Journal of Economic Literature, American Economic Association, 49:2, 326-65.

Tabuchi T, (1986), "Existence and stability of city-size distribution in the gravity and logit models" Environment and Planning, 18(10) 1375 - 1389

Vernon, R., (1966). "International investment and international trade in the product cycle", Quarterly Journal of Economics, 80, 190-207.

Wagner, J., (2007). "Exports and Productivity: A Survey of the Evidence from Firm-level Data",The World Economy, Wiley Blackwell, 30:1, 60-82. 
TABLE SECTION

Table 1: Summary statistics.

Three different proxies for innovative exporters and three different types of locations

Sample size 9,580

\begin{tabular}{|c|c|c|c|c|c|c|c|c|c|c|c|c|c|c|c|c|c|c|}
\hline \multirow[b]{3}{*}{ Spillover } & \multicolumn{6}{|c|}{ I. Persistent exporters } & \multicolumn{6}{|c|}{ II. New export products } & \multicolumn{6}{|c|}{ III. Patents } \\
\hline & \multicolumn{3}{|c|}{$\begin{array}{c}\text { Some years with no exports } \\
51.3 \%\end{array}$} & \multicolumn{3}{|c|}{$\begin{array}{c}\text { Exporting all years } \\
48.7 \%\end{array}$} & \multicolumn{3}{|c|}{$\begin{array}{c}\text { Identical Products } \\
79.6 \%\end{array}$} & \multicolumn{3}{|c|}{$\begin{array}{l}\text { Introduction of } 4 \mathrm{New} \\
\text { Product: } 20.4 \%\end{array}$} & \multicolumn{3}{|c|}{$\begin{array}{c}\text { Applications <2 years: } 91.4 \\
91.5 \%\end{array}$} & \multicolumn{3}{|c|}{$\begin{array}{c}\text { Applications } 2 \text { years or more: } \\
8.5 \%\end{array}$} \\
\hline & Low & Med & High & Low & Med & High & Low & Med & High & Low & Med & High & Low & Med & High & Low & Med & High \\
\hline Level, $\log$ VA & $\begin{array}{l}15.94 \\
(0.92)\end{array}$ & $\begin{array}{r}16.03 \\
(1.09)\end{array}$ & $\begin{array}{l}16.14 \\
(1.33)\end{array}$ & $\begin{array}{r}16.85 \\
(1.27)\end{array}$ & $\begin{array}{l}16.98 \\
(1.46)\end{array}$ & $\begin{array}{l}17.16 \\
(1.63)\end{array}$ & $\begin{array}{r}16.15 \\
(1.03)\end{array}$ & $\begin{array}{l}16.17 \\
(1.11)\end{array}$ & $\begin{array}{l}16.19 \\
(1.31)\end{array}$ & $\begin{array}{l}17.19 \\
(1.34)\end{array}$ & $\begin{array}{r}17.36 \\
(1.57)\end{array}$ & $\begin{array}{r}17.53 \\
(1.70)\end{array}$ & $\begin{array}{r}16.29 \\
(1.11)\end{array}$ & $\begin{array}{l}16.32 \\
(1.19)\end{array}$ & $\begin{array}{l}16.34 \\
(1.39)\end{array}$ & $\begin{array}{l}17.50 \\
(1.45)\end{array}$ & $\begin{array}{l}17.88 \\
(1.77)\end{array}$ & $\begin{array}{l}17.95 \\
(1.82)\end{array}$ \\
\hline Growth, log VA & $\begin{array}{r}5.2 \% \\
(0.40)\end{array}$ & $\begin{array}{r}4.6 \% \\
(0.44)\end{array}$ & $\begin{array}{r}3.1 \% \\
(0.53)\end{array}$ & $\begin{array}{r}2.7 \% \\
(0.41)\end{array}$ & $\begin{array}{r}3.1 \% \\
(0.46)\end{array}$ & $\begin{array}{r}2.7 \% \\
(0.56)\end{array}$ & $\begin{array}{r}4.1 \% \\
(0.42)\end{array}$ & $\begin{array}{r}3.3 \% \\
(0.47)\end{array}$ & $\begin{array}{r}2.9 \% \\
(0.55)\end{array}$ & $\begin{array}{r}3.6 \% \\
(0.36)\end{array}$ & $\begin{array}{r}5.1 \% \\
(0.40)\end{array}$ & $\begin{array}{r}3.2 \% \\
(0.51)\end{array}$ & $\begin{array}{r}4.0 \% \\
(0.40)\end{array}$ & $\begin{array}{r}3.8 \% \\
(0.46)\end{array}$ & $\begin{array}{r}2.5 \% \\
(0.54)\end{array}$ & $\begin{array}{r}3.4 \% \\
(0.45)\end{array}$ & $\begin{array}{r}3.9 \% \\
(0.42)\end{array}$ & $\begin{array}{r}5.9 \% \\
(0.57)\end{array}$ \\
\hline Level, log TFP & $\begin{array}{l}14.55 \\
(0.56)\end{array}$ & $\begin{array}{r}14.59 \\
(0.68)\end{array}$ & $\begin{array}{r}14.66 \\
(0.81)\end{array}$ & $\begin{array}{r}14.94 \\
(0.68)\end{array}$ & $\begin{array}{r}14.99 \\
(0.76)\end{array}$ & $\begin{array}{r}15.11 \\
(0.91)\end{array}$ & $\begin{array}{r}14.64 \\
(0.61)\end{array}$ & $\begin{array}{r}14.64 \\
(0.66)\end{array}$ & $\begin{array}{l}14.68 \\
(0.81)\end{array}$ & $\begin{array}{r}15.08 \\
(0.68)\end{array}$ & $\begin{array}{r}15.18 \\
(0.83)\end{array}$ & $\begin{array}{r}15.27 \\
(0.93)\end{array}$ & $\begin{array}{r}14.59 \\
(0.62)\end{array}$ & $\begin{array}{l}14.71 \\
(0.67)\end{array}$ & $\begin{array}{r}14.75 \\
(0.80)\end{array}$ & $\begin{array}{l}15.22 \\
(0.76)\end{array}$ & $\begin{array}{l}15.42 \\
(0.97)\end{array}$ & $\begin{array}{r}15.49 \\
(1.13)\end{array}$ \\
\hline Growth, log TFP & $\begin{array}{r}4.3 \% \\
(0.38)\end{array}$ & $\begin{array}{r}3.9 \% \\
(0.42)\end{array}$ & $\begin{array}{r}3.6 \% \\
(0.51)\end{array}$ & $\begin{array}{r}2.1 \% \\
(0.41)\end{array}$ & $\begin{array}{r}2.7 \% \\
(0.45)\end{array}$ & $\begin{array}{r}4.0 \% \\
(0.59)\end{array}$ & $\begin{array}{r}3.5 \% \\
(0.41)\end{array}$ & $\begin{array}{r}3.4 \% \\
(0.45)\end{array}$ & $\begin{array}{r}4.2 \% \\
(0.55)\end{array}$ & $\begin{array}{r}1.9 \% \\
(0.35)\end{array}$ & $\begin{array}{r}3.0 \% \\
(0.39)\end{array}$ & $\begin{array}{r}2.5 \% \\
(0.54)\end{array}$ & $\begin{array}{r}3.3 \% \\
(0.39)\end{array}$ & $\begin{array}{r}3.4 \% \\
(0.44)\end{array}$ & $\begin{array}{r}3.7 \% \\
(0.54)\end{array}$ & $\begin{array}{r}1.8 \% \\
(0.44)\end{array}$ & $\begin{array}{r}2.6 \% \\
(0.43)\end{array}$ & $\begin{array}{r}4.3 \% \\
(0.58)\end{array}$ \\
\hline Exports per Emp, log & $\begin{array}{r}9.06 \\
(2.53) \\
\end{array}$ & $\begin{array}{r}8.74 \\
(2.64)\end{array}$ & $\begin{array}{r}8.05 \\
(2.86) \\
\end{array}$ & $\begin{array}{r}12.73 \\
(1.41)\end{array}$ & $\begin{array}{r}12.86 \\
(1.52)\end{array}$ & $\begin{array}{r}12.97 \\
(1.57)\end{array}$ & $\begin{array}{r}10.82 \\
(2.73) \\
\end{array}$ & $\begin{array}{r}10.37 \\
(2.96)\end{array}$ & $\begin{array}{r}9.39 \\
(3.37) \\
\end{array}$ & $\begin{array}{r}12.65 \\
(1.68)\end{array}$ & $\begin{array}{r}12.88 \\
(1.73)\end{array}$ & $\begin{array}{r}11.21 \\
(2.81)\end{array}$ & $\begin{array}{r}11.16 \\
(2.63)\end{array}$ & $\begin{array}{r}10.89 \\
(2.86)\end{array}$ & $\begin{array}{r}10.07 \\
(3.34) \\
\end{array}$ & $\begin{array}{r}12.92 \\
(1.73) \\
\end{array}$ & $\begin{array}{r}13.24 \\
(1.88)\end{array}$ & $\begin{array}{r}12.87 \\
(2.43)\end{array}$ \\
\hline EMP & $\begin{array}{r}34 \\
(110)\end{array}$ & $\begin{array}{r}52 \\
(225)\end{array}$ & $\begin{array}{r}102 \\
(766)\end{array}$ & $\begin{array}{r}104 \\
(285)\end{array}$ & $\begin{array}{r}174 \\
(783)\end{array}$ & $\begin{array}{r}233 \\
(991)\end{array}$ & $\begin{array}{r}43 \\
(107)\end{array}$ & $\begin{array}{r}50 \\
(164)\end{array}$ & $\begin{array}{r}78 \\
(330)\end{array}$ & $\begin{array}{r}152 \\
(393)\end{array}$ & $\begin{array}{r}274 \\
(1,041)\end{array}$ & $\begin{array}{r}366 \\
(1,575)\end{array}$ & $\begin{array}{r}54 \\
(121)\end{array}$ & $\begin{array}{r}64 \\
(214)\end{array}$ & $\begin{array}{r}114 \\
(668)\end{array}$ & $\begin{array}{r}219 \\
(588)\end{array}$ & $\begin{array}{r}484 \\
(1,536)\end{array}$ & $\begin{array}{r}430 \\
(1,668)\end{array}$ \\
\hline Growth, EMP & $\begin{array}{c}0.90 \\
(15.58)\end{array}$ & $\begin{array}{r}0.81 \\
(38.87)\end{array}$ & $\begin{array}{r}3.02 \\
(345.9)\end{array}$ & $\begin{array}{r}0.29 \\
(48.70)\end{array}$ & $\begin{array}{r}2.41 \\
(132.3)\end{array}$ & $\begin{array}{r}-1.60 \\
(134.9)\end{array}$ & $\begin{array}{r}0.40 \\
(18.73)\end{array}$ & $\begin{array}{r}0.23 \\
(29.75)\end{array}$ & $\begin{array}{r}-1.02 \\
(58.87)\end{array}$ & $\begin{array}{r}1.14 \\
(65.03)\end{array}$ & $\begin{array}{r}5.00 \\
(174.6)\end{array}$ & $\begin{array}{r}7.16 \\
(532.5)\end{array}$ & $\begin{array}{r}0.72 \\
(30.66)\end{array}$ & $\begin{array}{r}0.70 \\
(51.88)\end{array}$ & $\begin{array}{r}-0.57 \\
(88.17)\end{array}$ & $\begin{array}{r}-0.60 \\
(70.39)\end{array}$ & $\begin{array}{r}8.27 \\
(242.6)\end{array}$ & $\begin{array}{r}13.28 \\
(754.2)\end{array}$ \\
\hline PC, $\log$ & $\begin{array}{r}14.13 \\
(2.67)\end{array}$ & $\begin{array}{r}13.75 \\
(3.42)\end{array}$ & $\begin{array}{r}13.48 \\
(3.79)\end{array}$ & $\begin{array}{r}15.26 \\
(2.67)\end{array}$ & $\begin{array}{r}15.06 \\
(3.19)\end{array}$ & $\begin{array}{r}14.80 \\
(3.65)\end{array}$ & $\begin{array}{r}14.43 \\
(2.77)\end{array}$ & $\begin{array}{r}14.01 \\
(3.37)\end{array}$ & $\begin{array}{r}13.53 \\
(3.81)\end{array}$ & $\begin{array}{r}15.56 \\
(2.41)\end{array}$ & $\begin{array}{r}15.37 \\
(3.19)\end{array}$ & $\begin{array}{r}15.31 \\
(3.42)\end{array}$ & $\begin{array}{r}14.59 \\
(2.72)\end{array}$ & $\begin{array}{r}14.17 \\
(3.35)\end{array}$ & $\begin{array}{r}13.72 \\
(3.76)\end{array}$ & $\begin{array}{r}15.83 \\
(2.50)\end{array}$ & $\begin{array}{r}16.06 \\
(3.07)\end{array}$ & $\begin{array}{r}15.95 \\
(3.44)\end{array}$ \\
\hline Growth, $\log$ PC & $\begin{array}{r}-0.06 \\
(2.60)\end{array}$ & $\begin{array}{l}-0.11 \\
(2.60\end{array}$ & $\begin{array}{r}-0.17 \\
(2.96)\end{array}$ & $\begin{array}{r}-0.07 \\
(1.79)\end{array}$ & $\begin{array}{r}-0.10 \\
(2.19)\end{array}$ & $\begin{array}{r}-0.17 \\
(2.79)\end{array}$ & $\begin{array}{r}-0.08 \\
(2.08)\end{array}$ & $\begin{array}{r}-0.14 \\
(2.58)\end{array}$ & $\begin{array}{r}-0.20 \\
(3.07)\end{array}$ & $\begin{array}{r}-0.01 \\
(1.46)\end{array}$ & $\begin{array}{r}-0.03 \\
(1.91)\end{array}$ & $\begin{array}{r}-0.08 \\
(2.36)\end{array}$ & $\begin{array}{r}-0.07 \\
(1.98)\end{array}$ & $\begin{array}{r}-0.11 \\
(2.46)\end{array}$ & $\begin{array}{r}-0.18 \\
(2.99)\end{array}$ & $\begin{array}{r}-0.01 \\
(1.57)\end{array}$ & $\begin{array}{r}-0.06 \\
(1.97)\end{array}$ & $\begin{array}{l}-0.08 \\
(2.18)\end{array}$ \\
\hline $\mathrm{HC}$ & $\begin{array}{r}2.9 \% \\
(0.06)\end{array}$ & $\begin{array}{r}5.5 \% \\
(0.11)\end{array}$ & $\begin{array}{r}9.9 \% \\
(0.15)\end{array}$ & $\begin{array}{r}4.6 \% \\
(0.07)\end{array}$ & $\begin{array}{r}9.2 \% \\
(0.12)\end{array}$ & $\begin{array}{l}14.0 \% \\
(0.15)\end{array}$ & $\begin{array}{r}3.2 \% \\
(0.06)\end{array}$ & $\begin{array}{r}6.1 \% \\
(0.11)\end{array}$ & $\begin{array}{l}10.4 \% \\
(0.15)\end{array}$ & $\begin{array}{r}5.3 \% \\
(0.07)\end{array}$ & $\begin{array}{r}10.5 \% \\
(0.11)\end{array}$ & $\begin{array}{r}14.8 \% \\
(0.14)\end{array}$ & $\begin{array}{r}3.3 \% \\
(0.06)\end{array}$ & $\begin{array}{r}6.3 \% \\
(0.10)\end{array}$ & $\begin{array}{r}10.4 \% \\
(0.14)\end{array}$ & $\begin{array}{r}7.8 \% \\
(0.10)\end{array}$ & $\begin{array}{l}15.1 \% \\
(0.15)\end{array}$ & $\begin{array}{r}19.6 \% \\
(0.17)\end{array}$ \\
\hline EP & $\begin{array}{r}6.34 \\
(3.78) \\
\end{array}$ & $\begin{array}{r}6.18 \\
(3.78) \\
\end{array}$ & $\begin{array}{r}6.02 \\
(3.76) \\
\end{array}$ & $\begin{array}{r}10.37 \\
(2.77) \\
\end{array}$ & $\begin{array}{r}10.03 \\
(2.91) \\
\end{array}$ & $\begin{array}{r}9.49 \\
(3.23) \\
\end{array}$ & $\begin{array}{r}7.48 \\
(3.93) \\
\end{array}$ & $\begin{array}{r}7.00 \\
(3.91) \\
\end{array}$ & $\begin{array}{r}6.30 \\
(3.82) \\
\end{array}$ & $\begin{array}{r}11.22 \\
(1.67)\end{array}$ & $\begin{array}{r}10.83 \\
(2.06)\end{array}$ & $\begin{array}{r}10.43 \\
(2.37)\end{array}$ & $\begin{array}{r}8.14 \\
(3.9)\end{array}$ & $\begin{array}{l}7.71 \\
(3.9)\end{array}$ & $\begin{array}{r}6.95 \\
(3.9)\end{array}$ & $\begin{array}{r}10.87 \\
(2.2)\end{array}$ & $\begin{array}{r}10.72 \\
(2.4)\end{array}$ & $\begin{array}{r}10.46 \\
(2.5)\end{array}$ \\
\hline OW1 & 0.47 & 0.40 & 0.41 & 0.24 & 0.20 & 0.18 & 0.41 & 0.36 & 0.38 & 0.18 & 0.16 & 0.14 & 0.37 & 0.34 & 0.35 & 0.14 & 0.12 & 0.12 \\
\hline OW2 & & 0.40 & 0.34 & & 0.21 & & 0.35 & 0.36 & & 0.25 & 0.19 & 0.19 & 0.35 & 0.33 & 0.30 & $0.1^{1}$ & 0.11 & 0.15 \\
\hline OW3 & 0.11 & 0.12 & 0.14 & 0.29 & 0.33 & 0.31 & 0.16 & 0.17 & 0.17 & 0.35 & 0.35 & 0.32 & 0.18 & 0.19 & 0.18 & 0.43 & 0.49 & 0.40 \\
\hline OW4 & 0.04 & 0.08 & 0.11 & 0.19 & 0.26 & 0.30 & 0.08 & 0.11 & 0.13 & 0.22 & 0.30 & 0.35 & 0.10 & 0.14 & 0.17 & 0.26 & 0.28 & 0.33 \\
\hline Sum & 1.00 & 1.00 & 1.00 & 1.00 & 1.00 & 1.00 & 1.00 & 1.00 & 1.00 & 1.00 & 1.00 & 1.00 & 1.00 & 1.00 & 1.00 & 1.00 & 1.00 & 1.00 \\
\hline Share of total Export & $0.4 \%$ & $0.7 \%$ & $1.0 \%$ & 20.7 & $28,9 \%$ & $48.3 \%$ & $1.9 \%$ & $5.1 \%$ & $8.8 \%$ & $19.3 \%$ & $20.8 \%$ & $44.2 \%$ & $6.7 \%$ & $11.7 \%$ & $11.8 \%$ & $14.5 \%$ & $17.8 \%$ & $37.6 \%$ \\
\hline Unique firms & 2,313 & 1,793 & 810 & 2,441 & 1,677 & 546 & 3,830 & 2,721 & 1,076 & 924 & 749 & 280 & 4,379 & 3,160 & 1,224 & 375 & 310 & 132 \\
\hline Obs, total & 19,364 & 13,755 & 5,531 & 20,338 & 13,047 & 3,572 & 29,968 & 19,417 & 6,717 & 9,784 & 7,385 & 2,386 & 35,920 & 23,733 & 7,975 & 3,832 & 3,069 & 1,128 \\
\hline Obs, fraction & 0.26 & 0.18 & 0.07 & 0.27 & 0.17 & 0.05 & 0.39 & 0.26 & 0.09 & 0.13 & 0.10 & 0.03 & 0.47 & 0.31 & 0.11 & 0.05 & 0.04 & 0.02 \\
\hline
\end{tabular}

Note: VA: Log value added, TFP: log total factor productivity, EMP: Log employment, PC: Log physical capital, HC: Human capital, fraction, EP: Years of export

participation, OW1: Domestic non-affiliate enterprises, OW2: Domestic group enterprises, OW3: Domestic multinational enterprises, OW4: Foreign multinational enterprises 
Table 2: Level Log of Productivity. Dynamic GMM

\begin{tabular}{|c|c|c|c|c|c|c|}
\hline & \multicolumn{2}{|c|}{ I. Export Persistency } & \multicolumn{2}{|c|}{ II. New Products } & \multicolumn{2}{|c|}{ III. Patent } \\
\hline & Log VA & Log TFP & Log VA & Log TFP & Log VA & Log TFP \\
\hline IS1 & Ref & Ref & Ref & Ref & Ref & Ref \\
\hline IS2 & $\begin{array}{c}0.007 \\
(0.007)\end{array}$ & $\begin{array}{c}0.010 \\
(0.008)\end{array}$ & $\begin{array}{c}0.000 \\
(0.006)\end{array}$ & $\begin{array}{l}-0.002 \\
(0.007)\end{array}$ & $\begin{array}{l}0.011^{*} \\
(0.006)\end{array}$ & $\begin{array}{c}0.002 \\
(0.007)\end{array}$ \\
\hline IS3 & $\begin{array}{c}0.011 \\
(0.015)\end{array}$ & $\begin{array}{c}0.025 \\
(0.016)\end{array}$ & $\begin{array}{c}0.002 \\
(0.014)\end{array}$ & $\begin{array}{c}0.014 \\
(0.015)\end{array}$ & $\begin{array}{l}0.024 * \\
(0.013)\end{array}$ & $\begin{array}{c}0.019 \\
(0.015)\end{array}$ \\
\hline IS4 & $\begin{array}{l}0.025^{*} \\
(0.015)\end{array}$ & $\begin{array}{c}0.009 \\
(0.012)\end{array}$ & $\begin{array}{c}0.027 \\
(0.021)\end{array}$ & $\begin{array}{c}0.013 \\
(0.018)\end{array}$ & $\begin{array}{l}0.034^{*} \\
(0.021)\end{array}$ & $\begin{array}{c}0.030 \\
(0.021)\end{array}$ \\
\hline IS5 & $\begin{array}{l}0.032 * \\
(0.017)\end{array}$ & $\begin{array}{c}0.014 \\
(0.013)\end{array}$ & $\begin{array}{l}0.048^{*} \\
(0.025)\end{array}$ & $\begin{array}{c}0.040 * * \\
(0.020)\end{array}$ & $\begin{array}{c}0.064 * * \\
(0.031)\end{array}$ & $\begin{array}{c}0.069^{* *} \\
(0.033)\end{array}$ \\
\hline IS6 & $\begin{array}{l}0.047^{*} \\
(0.026)\end{array}$ & $\begin{array}{c}0.048 * * \\
(0.023)\end{array}$ & $\begin{array}{l}0.068^{*} \\
(0.035)\end{array}$ & $\begin{array}{c}0.075^{* *} \\
(0.029)\end{array}$ & $\begin{array}{c}0.084 * * \\
(0.039)\end{array}$ & $\begin{array}{c}0.116^{* *} \\
(0.046)\end{array}$ \\
\hline EMP, log & $\begin{array}{c}1.315^{* * *} \\
(0.162)\end{array}$ & $\begin{array}{c}0.298 * * * \\
(0.089)\end{array}$ & $\begin{array}{c}1.294 * * * \\
(0.161)\end{array}$ & $\begin{array}{c}0.285 * * * \\
(0.091)\end{array}$ & $\begin{array}{c}1.018 * * * \\
(0.105)\end{array}$ & $\begin{array}{c}0.295^{* * * *} \\
(0.089)\end{array}$ \\
\hline EMP t-1 & $\begin{array}{c}-0.926 * * * \\
(0.177)\end{array}$ & $\begin{array}{l}-0.120 \\
(0.086)\end{array}$ & $\begin{array}{c}-0.900 * * * \\
(0.175)\end{array}$ & $\begin{array}{l}-0.105 \\
(0.086)\end{array}$ & $\begin{array}{c}-0.583 * * * \\
(0.108)\end{array}$ & $\begin{array}{l}-0.115 \\
(0.086)\end{array}$ \\
\hline $\mathrm{PC}, \log$ & $\begin{array}{c}0.019 \\
(0.016)\end{array}$ & $\begin{array}{l}-0.000 \\
(0.010)\end{array}$ & $\begin{array}{c}0.019 \\
(0.016)\end{array}$ & $\begin{array}{l}-0.001 \\
(0.010)\end{array}$ & $\begin{array}{c}0.046^{* * *} \\
(0.010)\end{array}$ & $\begin{array}{l}-0.001 \\
(0.010)\end{array}$ \\
\hline $\mathrm{PC}$ t-1 & $\begin{array}{l}-0.011 \\
(0.016)\end{array}$ & $\begin{array}{c}0.013 \\
(0.009)\end{array}$ & $\begin{array}{l}-0.011 \\
(0.016)\end{array}$ & $\begin{array}{c}0.013 \\
(0.009)\end{array}$ & $\begin{array}{c}-0.025 * * * \\
(0.010)\end{array}$ & $\begin{array}{c}0.013 \\
(0.010)\end{array}$ \\
\hline $\mathrm{HC}, \%$ & $\begin{array}{c}1.474 \\
(0.905)\end{array}$ & $\begin{array}{c}0.331 \\
(0.493)\end{array}$ & $\begin{array}{c}1.452 \\
(0.892)\end{array}$ & $\begin{array}{c}0.337 \\
(0.488)\end{array}$ & $\begin{array}{c}0.726 \\
(0.692)\end{array}$ & $\begin{array}{c}0.372 \\
(0.491)\end{array}$ \\
\hline $\mathrm{HC} \mathrm{t}-1$ & $\begin{array}{l}-1.107 \\
(0.844)\end{array}$ & $\begin{array}{l}-0.019 \\
(0.438)\end{array}$ & $\begin{array}{l}-1.081 \\
(0.831)\end{array}$ & $\begin{array}{l}-0.023 \\
(0.433)\end{array}$ & $\begin{array}{l}-0.383 \\
(0.633)\end{array}$ & $\begin{array}{l}-0.061 \\
(0.433)\end{array}$ \\
\hline EP & $\begin{array}{l}0.004 * \\
(0.002)\end{array}$ & $\begin{array}{c}0.003^{* *} \\
(0.002)\end{array}$ & $\begin{array}{c}0.004 * * \\
(0.002)\end{array}$ & $\begin{array}{l}0.003 * \\
(0.001)\end{array}$ & $\begin{array}{c}0.004 * * \\
(0.002)\end{array}$ & $\begin{array}{l}0.003^{*} \\
(0.002)\end{array}$ \\
\hline OW2 & $\begin{array}{l}0.019 * \\
(0.011)\end{array}$ & $\begin{array}{c}0.014 \\
(0.009)\end{array}$ & $\begin{array}{l}0.019^{*} \\
(0.010)\end{array}$ & $\begin{array}{c}0.013 \\
(0.009)\end{array}$ & $\begin{array}{c}0.019^{* *} \\
(0.008)\end{array}$ & $\begin{array}{c}0.014 \\
(0.009)\end{array}$ \\
\hline OW3 & $\begin{array}{c}0.047 \\
(0.041)\end{array}$ & $\begin{array}{c}0.036 \\
(0.029)\end{array}$ & $\begin{array}{c}0.046 \\
(0.037)\end{array}$ & $\begin{array}{c}0.030 \\
(0.028)\end{array}$ & $\begin{array}{c}0.034 \\
(0.027)\end{array}$ & $\begin{array}{c}0.028 \\
(0.028)\end{array}$ \\
\hline OW4 & $\begin{array}{c}0.054 \\
(0.049)\end{array}$ & $\begin{array}{c}0.042 \\
(0.035)\end{array}$ & $\begin{array}{c}0.052 \\
(0.044)\end{array}$ & $\begin{array}{c}0.034 \\
(0.033)\end{array}$ & $\begin{array}{c}0.034 \\
(0.034)\end{array}$ & $\begin{array}{c}0.034 \\
(0.034)\end{array}$ \\
\hline Laglimits & (3 3) & (3.) & (3 3) & $(3)$. & (3.) & $(3)$. \\
\hline Instruments & 99 & 211 & 99 & 211 & 211 & 211 \\
\hline $\operatorname{AR}(2)$ & 0.188 & 0.589 & 0.186 & 0.580 & 0.137 & 0.607 \\
\hline Hansen & 0.164 & 0.096 & 0.174 & 0.088 & 0.387 & 0.095 \\
\hline
\end{tabular}

Note: $* * * \mathrm{p}<0.01, * * \mathrm{p}<0.05, * \mathrm{p}<0.1$. Standard errors in parentheses. Year dummies and 2-digit sector dummies included. Number of unique firms with 3 lags for the level equation is 6,882, Total observations 41,261.

(a) Reference is Domestic non-affiliate firms.

IS1: Non innovation, low spillovers, IS2: Non Innovation, medium spillovers, IS3: Non Innovation, high spillovers, IS4: Innovation, weak spillovers, IS5: Innovation, medium spillovers, IS6: Innovation, high spillovers, EMP: Employment; PC: Log physical capital, HC: Human capital, fraction, YE: Years of exports, OW1: Domestic non-affiliate enterprises, OW2: Domestic group enterprises, OW3: Domestic multinational enterprises, OW4: Foreign multinational enterprises. 
Table 3: Growth Log of Productivity. Dynamic GMM

\begin{tabular}{|c|c|c|c|c|c|c|}
\hline & \multicolumn{2}{|c|}{ I. Export persistency } & \multicolumn{2}{|c|}{ II. New products } & \multicolumn{2}{|c|}{ III. Patent } \\
\hline & $\Delta \log V A$ & $\Delta \log T F P$ & $\Delta \log \mathrm{VA}$ & $\Delta \log$ TFP & $\Delta \log \mathrm{VA}$ & $\Delta \log \mathrm{TFP}$ \\
\hline IS1 & Ref & Ref & Ref & Ref & Ref & Ref \\
\hline IS 2 & $\begin{array}{c}-0.002 \\
(0.005)\end{array}$ & $\begin{array}{c}-0.002 \\
(0.007)\end{array}$ & $\begin{array}{c}-0.007 \\
(0.005)\end{array}$ & $\begin{array}{c}-0.009 \\
(0.006)\end{array}$ & $\begin{array}{l}-0.004 \\
(0.005)\end{array}$ & $\begin{array}{c}-0.008 \\
(0.006)\end{array}$ \\
\hline IS3 & $\begin{array}{l}-0.006 \\
(0.010)\end{array}$ & $\begin{array}{c}0.003 \\
(0.013)\end{array}$ & $\begin{array}{l}-0.009 \\
(0.010)\end{array}$ & $\begin{array}{l}-0.004 \\
(0.012)\end{array}$ & $\begin{array}{l}-0.010 \\
(0.010)\end{array}$ & $\begin{array}{l}-0.003 \\
(0.011)\end{array}$ \\
\hline IS4 & $\begin{array}{c}0.029 * * \\
(0.013)\end{array}$ & $\begin{array}{c}0.039 * * * \\
(0.013)\end{array}$ & $\begin{array}{c}0.057 * * * \\
(0.022)\end{array}$ & $\begin{array}{c}0.061 * * * \\
(0.018)\end{array}$ & $\begin{array}{c}0.055^{* *} \\
(0.026)\end{array}$ & $\begin{array}{c}0.072 * * * \\
(0.025)\end{array}$ \\
\hline IS5 & $\begin{array}{c}0.033 * * \\
(0.014)\end{array}$ & $\begin{array}{c}0.040 * * * \\
(0.013)\end{array}$ & $\begin{array}{c}0.072 * * * \\
(0.024)\end{array}$ & $\begin{array}{c}0.076 * * * \\
(0.022)\end{array}$ & $\begin{array}{c}0.088^{* *} * \\
(0.037)\end{array}$ & $\begin{array}{c}0.120 * * * \\
(0.039)\end{array}$ \\
\hline IS6 & $\begin{array}{l}0.035^{*} \\
(0.020)\end{array}$ & $\begin{array}{c}0.065^{* * * *} \\
(0.023)\end{array}$ & $\begin{array}{c}0.063^{* *} \\
(0.030)\end{array}$ & $\begin{array}{c}0.097 * * * \\
(0.033)\end{array}$ & $\begin{array}{c}0.096^{* * *} \\
(0.041)\end{array}$ & $\begin{array}{c}0.156^{* * * *} \\
(0.049)\end{array}$ \\
\hline$\Delta \mathrm{EMP}$ & $\begin{array}{c}0.479 * * * \\
(0.107)\end{array}$ & $\begin{array}{c}0.140 \\
(0.098)\end{array}$ & $\begin{array}{c}0.472 * * * \\
(0.107)\end{array}$ & $\begin{array}{c}0.141 \\
(0.098)\end{array}$ & $\begin{array}{c}0.481 * * * \\
(0.107)\end{array}$ & $\begin{array}{c}0.145 \\
(0.097)\end{array}$ \\
\hline$\Delta \mathrm{EMP} \mathrm{t}-1$ & $\begin{array}{c}0.393 * * * \\
(0.141)\end{array}$ & $\begin{array}{c}0.158 \\
(0.137)\end{array}$ & $\begin{array}{c}0.389 * * * \\
(0.141)\end{array}$ & $\begin{array}{c}0.160 \\
(0.138)\end{array}$ & $\begin{array}{c}0.397 * * * \\
(0.141)\end{array}$ & $\begin{array}{c}0.164 \\
(0.137)\end{array}$ \\
\hline$\Delta \mathrm{PC}$ & $\begin{array}{c}0.031 * * * \\
(0.011)\end{array}$ & $\begin{array}{c}-0.001 \\
(0.011)\end{array}$ & $\begin{array}{c}0.030 * * * \\
(0.011)\end{array}$ & $\begin{array}{l}-0.001 \\
(0.011)\end{array}$ & $\begin{array}{c}0.030 * * * \\
(0.011)\end{array}$ & $\begin{array}{l}-0.003 \\
(0.011)\end{array}$ \\
\hline$\Delta \mathrm{PC} \mathrm{t}-1$ & $\begin{array}{c}0.014 \\
(0.013)\end{array}$ & $\begin{array}{l}-0.001 \\
(0.013)\end{array}$ & $\begin{array}{c}0.013 \\
(0.013)\end{array}$ & $\begin{array}{l}-0.002 \\
(0.012)\end{array}$ & $\begin{array}{c}0.013 \\
(0.013)\end{array}$ & $\begin{array}{l}-0.003 \\
(0.013)\end{array}$ \\
\hline $\mathrm{HC}, \%$ & $\begin{array}{c}0.544 \\
(0.402)\end{array}$ & $\begin{array}{c}0.397 \\
(0.428)\end{array}$ & $\begin{array}{c}0.569 \\
(0.404)\end{array}$ & $\begin{array}{c}0.436 \\
(0.433)\end{array}$ & $\begin{array}{c}0.565 \\
(0.406)\end{array}$ & $\begin{array}{c}0.428 \\
(0.433)\end{array}$ \\
\hline $\mathrm{HC} \mathrm{t}-1$ & $\begin{array}{c}0.544 \\
(0.402)\end{array}$ & $\begin{array}{c}0.397 \\
(0.428)\end{array}$ & $\begin{array}{c}-0.518 \\
(0.386)\end{array}$ & $\begin{array}{l}-0.208 \\
(0.408)\end{array}$ & $\begin{array}{c}-0.544 \\
(0.389)\end{array}$ & $\begin{array}{c}-0.228 \\
(0.407)\end{array}$ \\
\hline EP & $\begin{array}{c}0.006 * * * \\
(0.002)\end{array}$ & $\begin{array}{c}0.006^{* * * *} \\
(0.002)\end{array}$ & $\begin{array}{c}0.005^{* * *} * \\
(0.002)\end{array}$ & $\begin{array}{c}0.006 * * * \\
(0.002)\end{array}$ & $\begin{array}{c}0.006^{* * * *} \\
(0.002)\end{array}$ & $\begin{array}{c}0.007 * * * \\
(0.002)\end{array}$ \\
\hline VA t-1 & $\begin{array}{c}-0.092 * * \\
(0.037)\end{array}$ & & $\begin{array}{c}-0.092 * * \\
(0.038)\end{array}$ & & $\begin{array}{c}-0.081 * * \\
(0.036)\end{array}$ & \\
\hline TFP t-1 & & $\begin{array}{c}-0.596^{* * *} \\
(0.101)\end{array}$ & & $\begin{array}{c}-0.580 * * * \\
(0.101)\end{array}$ & & $\begin{array}{c}-0.575^{* * *} * \\
(0.099)\end{array}$ \\
\hline OW2 & $\begin{array}{c}0.021 * * \\
(0.010)\end{array}$ & $\begin{array}{c}0.024 * * \\
(0.011)\end{array}$ & $\begin{array}{l}0.020^{* *} \\
(0.010)\end{array}$ & $\begin{array}{l}0.020^{*} \\
(0.011)\end{array}$ & $\begin{array}{l}0.019^{*} \\
(0.010)\end{array}$ & $\begin{array}{c}0.021^{* *} \\
(0.011)\end{array}$ \\
\hline OW3 & $\begin{array}{l}0.077 * * \\
(0.038)\end{array}$ & $\begin{array}{c}0.109 * * * \\
(0.038)\end{array}$ & $\begin{array}{l}0.070 * \\
(0.037)\end{array}$ & $\begin{array}{c}0.092 * * \\
(0.036)\end{array}$ & $\begin{array}{l}0.061 * \\
(0.035)\end{array}$ & $\begin{array}{c}0.089 * * * \\
(0.034)\end{array}$ \\
\hline OW4 & $\begin{array}{l}0.086^{*} \\
(0.046)\end{array}$ & $\begin{array}{c}0.131 * * * \\
(0.046)\end{array}$ & $\begin{array}{l}0.077 * \\
(0.045)\end{array}$ & $\begin{array}{c}0.110^{* *} \\
(0.043)\end{array}$ & $\begin{array}{c}0.069 \\
(0.043)\end{array}$ & $\begin{array}{c}0.110^{* * * *} \\
(0.042)\end{array}$ \\
\hline Laglimits & (3.) & (3.) & (3.) & $(3)$. & $(3)$. & (3.) \\
\hline Instruments & 181 & 181 & 181 & 181 & 181 & 181 \\
\hline $\operatorname{AR}(2)$ & 0.202 & 0.284 & 0.203 & 0.274 & 0.195 & 0.252 \\
\hline Hansen & 0.277 & 0.348 & 0.259 & 0.348 & 0.252 & 0.292 \\
\hline
\end{tabular}

Note: $* * * \mathrm{p}<0.01, * * \mathrm{p}<0.05, * \mathrm{p}<0.1$. Standard errors in parentheses. Year dummies and 2-digit sector dummies included. Number of unique firms in the growth regression with 3 lags is 6,310, Total observations: 34,358 .

(a) Reference is Domestic non-affiliate firms.

IS1: Non innovation, low spillovers, IS2: Non Innovation, medium spillovers, IS3: Non Innovation, high spillovers, IS4: Innovation, weak spillovers, IS5: Innovation, medium spillovers, IS6: Innovation, high spillovers, EMP: Employment; PC: Log physical capital, HC: Human capital, fraction, YE: Years of exports, VA: Log value added, TFP: Log total factor productivity, OW1: Domestic non-affiliate enterprises, OW2: Domestic group enterprises, OW3: Domestic multinational enterprises, OW4: Foreign multinational enterprises. 